\title{
IAMJ
}

INTERNATIONAL

AYURVEDIC

MEDICAL JOURNAL

\section{EVALUATION OF EFFICACY OF DARUHARIDRA CHANDANA MALAHARA LEPA AND PANCHAVALKALA MALAHARA LEPA IN PARIKARTIKA WITH SPECIAL REFERENCE TO ACUTE FISSURE IN ANO}

\author{
Suresh Y. Bhajantri' ${ }^{1}$ P. G. Gannur ${ }^{2}$ R. S. Gujar ${ }^{3}$ \\ ${ }^{1}$ Post Graduate Scholar, ${ }^{2}$ Professor and HOD, Dept. of Shalya Tantra, ${ }^{3}$ Assistant Professor, \\ Dept. of Shalya Tantra, BLDEA’S AVS Ayurveda Mahavidyalaya, Vijayapura, Karnataka, India
}

Corresponding Author:surisureshyb@gmail.com

https://doi.org/10.46607/iamj0409082021

(Published Online: August 2021)

Open Access

(C) International Ayurvedic Medical Journal, India 2021

Article Received:09/07//2021 - Peer Reviewed:14/07/2021 - Accepted for Publication:15/07/2021

\section{Check for updates}

\begin{abstract}
Background: Parikartika (Fissure-in-ano) is a clinical condition enrolled with the Laxana's like Kartanavat (cutting type of pain) and Chedanavat Shoola in the anal region and it can be correlated with Anal Fissure associated with Pain, Burning sensation during Defecation and tear in the distal Anal Canal. The Incidence rate of Anal Fissure is around 1 in 350 adults they occur equally common in men and women and most often occurs in adults aged 15 to 40. Aims and Objectives: To compare the Efficacy of Daruharidra Chandana Malahara with Panchavalkala Malahara in the Management of Parikartika (Acute fissure in ano). Materials and Methods: For the Present study, cases were selected from OPD and IPD of Shalya Tantra with the Classical Clinical Features like Kartanvat and Chedanavat Shoola in the anal region. Intervention: Daruharidra Chandana Malahara Lepa and Panchavalkala Malahara Lepa, applied Locally into Two Groups with each Group having 20 Patients for 7 days along with Triphala Choorna (1tsp) HS. Results: Copesetic Relief was seen in Signs and Symptoms and Improved Quality of Life after Treatment. Conclusion: The Study Was Proved that Parikartika was Effectively Managed by Daruharidra Chandana Malahara Lepa comparatively Panchavalkala Malahara Lepa.
\end{abstract}

Keywords: Parikartika, Fissure-in-ano, Daruharidra Chandana Malaharal Lepa, Panchavalkala Malahara Lepa. 


\section{INTRODUCTION}

Ayurveda implies the knowledge of life or the knowledge by which life may be prolonged. The health of an individual depends solely on his diet and lifestyle. But in this present era, due to Sedentary Lifestyle, Increased stress, Unhealthy diet regimen, Prolong sitting, Continuous travelling, sleep habits and various Lifestyle disorders are Increasing continuously. Thus, this leads to Agnimandya (Indigestion) and leading to an increase in the Incidence of Constipation in the Population, which causes too many Anorectal Diseases, most commonly being Haemorrhoids, Fistula-in-ano and Fissure in ano.Parikartika means "Parikruntavat vedana" i.e cutting type of pain specially observed in Gudapradesha(anal region). We get descriptions about Parikartika in Brihatrayees and later period Authors. of Ayurveda, but not as an Independent Disease. but as a Complication of Virecana, ${ }^{[1]}$, Basti, ${ }^{[2]}$ Grahani, ${ }^{[3]}$ Vyapath. In Parikartika due to Nidana's aggravated Apanavata attains Upward Movement and repelled by Udanavata, reaches Guda and obstruct the passage of Faeces producing severe Ruja, Gudadaha, Pichhasrava, which is very much suggestive of the Clinical Feature of Fissure-inano as per modern science. when it's limited to the Anal region. Fissure in- ano. was the most common cause of Pain in the Anal Canal; it was First recognised as a Disease in 1934. About 30- 40\% of the Population suffers from Proctologic Pathologies. at least once in their Lifetime. Anal Fissure comprises $10-15 \%$ of Ano-rectal Disorders. and it's characterised by Excruciating Pain during and after Defecation, Burning in nature, Bleeding per Rectum, with Spasm of Anal Sphincters. ${ }^{[4]}$ Pain may be so Severe that the Patient may avoid Defecation for days together until it becomes Inevitable.

Fissure occurs most commonly in Midline Posterior and less common in Anterior, thus protected part of the Anal Canal. Incidence is common in youngsters and adults (15-40 yrs), pregnant women and puerperal period. It is commonly seen in both Males and Females. It's very Painful Because of Injury to the Somatic Nerve Supply to the Anal region. Acute Fissure- in- ano usually takes $2-3$ weeks to heal even with the use of Stool Softeners and Topical Applications. Yet, some Fissures persist for more than 6 Weeks and are considered Chronic ones which show Reluctance to Heal For Parikartika, Acharyas have Described Treatments Both Local as well as Systemic but now where there is the given Description of Surgical Management. It seems in this Regard that they don't consider it to be a Disease, Complication of any Significance which Requires Surgical Intervention. It's described well by Acharya Sushruta, which must have the property of Vruna Ropana, Vedana Sthapana, Daha Prashamana and vata-pitta hara. Among Shasti Upakramas, Acharya Susruta mentions treatments like Pichu Basti, Anuvasana Basti, Matra Basti with Taila or Ghruta or manda along with sheetambu Pariseka and also Lepa ${ }^{[5]}$ as these does Ropana of Vruna $^{[6]}$.As a Parikartika is being one of the Vata and Pitta Vikara, Classically the First line of Treatment for vata vikara's the Basti, considering the Dosha's and Drugs of vata-pitta hara, Vruna Ropaka in nature. was taken in an Pertinence Form, applied with the help of Applicators, In Sushruta Samhita, Daruharidra, Chandana, ${ }^{[7]}$ and Panchavalkala (Nyagrodha, Udumbara, Ashwatha, Plaksha, Parisa), having the properties of Vrunaropaka, Vedanasthapaka, Dahaprashamaka, Raktasthambaka, and krimighna which helps to treat in Parikartika, hence it was taken up for this study.

Source of Data: Total 40 patients were divided into Group A \& Group B and Diagnosed Patients of Parikartika. following Inclusion Criteria approaching the OPD and IPD of BLDEA'S AVS AMV Vijayapura, were selected for the study.

Inclusion Criteria: Patients having the Following Features of Fissure-in-ano were Included in the study;

* Painful Defecation

* Burning Sensation

* Bleeding per Anum

* Constipation

* Anal Sphincter Spasm

* Presence of Solitary Fissure-in-ano

* Age Group between 18-65 


\section{Exclusion Criteria}

* Patient with any other Anorectal Diseases

* Uncontrolled Diabetes Mellitus and serious illness

* Pregnant and Lactating women

* Patients with Infectious Diseases of HIV and HbsAg Positive patients

* Fissures secondary to Ulcerative colitis, TB, Syphilis, IBS, and Crohn's disease and another Systemic Disease about Colo-rectum will be Excluded from the study.

Study Design: Randomly selected a Comparative Clinical Study.

\section{Intervention:}

\section{Poorva Karma}

The procedure was explained to the Patient in his/ her Language and Informed Consent was taken, required Materials were kept ready. The Patient was asked to Lie comfortably in the Lithotomy Position on the Examination Table. The part was cleaned with a Swab dipped in warm water, the Daruharidra Chandana Malahara. was taken in an Ointment Tube with an applicator was kept ready

Pradhana Karma: A Sterile Applicator is fixed with the Ointment Tube of Daruharidra Chandana Malahara. ask to take a deep breath and loose the sphincter, and gently inserted into the Anal Canal with Applicator and gently squeeze the ointment tube to the whole length of the Ulcer, and slowly remove it, a Sterile pad is kept in the place of Application.

\section{Paschal Karma}

After administration of the Malahara lepa, the patient was made to Lie in a Supine Position for 1520minutes. Triphala Choorna 1 karsha HS with warm water was given as a Stool softener.

The same Procedure was carried out Daily for 7 days

The same intervention of procedure is adopted for Group B also.

\section{Parameters}

\section{Subjective Parameters}

- Pain -Pain was grading on the severity of pain

- $\mathrm{G} 0$ - No pain

- G1-Pain during defecation
- G2-Pain during and after defecation which reduces within 30 minutes

- G3- Pain irrespective of defecation

\section{- Bleeding per Anum}

- G0- No bleeding

- G1- Bleeding with defecation

- G2- Bleeding after defecation

- G3- Irrespective bleeding

- Burning sensation

- G0- No burning sensation

- G1- Burning sensation during defecation

- G2- Burning during and after defecation which reduces after 30 minutes

- G3- Burning sensation irrespective of defecation

\section{Hard Stools}

- G0- Absent

- G1- Present

Objective Parameters

Tenderness

- G0- No tenderness

- G1- Mild with digital examination

- G2- Unable to perform a digital examination

- G3- Pin hole meatus

\section{Lenght of ulcer}

- G0-Healed ulcer

- G1-1 to $5 \mathrm{~mm}$

- $\mathrm{G} 2-5$ to $10 \mathrm{~mm}$

- $\mathrm{G} 3->10 \mathrm{~mm}$

3. Sphincter spasm

- G0- Relax sphincter

- G1- Two-finger

- G2- Index finger

- G3-Severe

4. Number of fissures

- G0- No- Fissure

- G1-One

- G2- Two

- G3-More than two

Overall Assessment and Result.

The Results were Evaluated by Subjective and Objective. Parameters mainly Based on Clinical Observation. by the Grading method. Assessment response 
was done in four groups as a Poor response, Moderate response, Good response, and Excellent response.

\section{Assessment of the total effect}

- Poor response $-<25 \%$ reduction in overall parameters.

- Moderate response - 26-50\% reduction in overall parameters.

- Good response - $51-75 \%$ reduction in overall parameters.

- Excellent response - $76-100 \%$ reduction in overall parameters.

\section{OBSERVATION}

The effect of Daruharidra Chandana Malahara Lepa was studied in 20 patients suffering from parikartika and Panchavalkala Malahara Lepa was studied in another 20 patients suffering from Parikartika (Acute fissure in ano), Fulfilling the Inclusion Criteria, the
Observations were as follows.A maximum number of Patients was in the Age Group between 30-39 years that are in Group A - 25\% and Group B- 35\%, followed by $30 \%$ in Group A and $15 \%$ in Group B in the age group between $40-49$ years, Followed by $5 \%$ in both the groups in the Age Group between 60years, Male patients were $50 \%$ in group A, $70 \%$ in group B, Female patients where $50 \%$ in group A, $30 \%$ in group B. $100 \%$ Patients were Middle Class in group A and $95 \%$ of patients in group B, 35\% patients were a Teacher in group A and 55\% patients in group B, 10$15 \%$ of Patients, were a Businessman in both the groups. Most of the Patients $95 \%$ were nonvegetarians, $35 \%$ patients were addicted to Alcohol and Smoking, $80 \%$ patients were having Mandagni, $50 \%$ patients were having Moderate built and $30 \%$ patients were having Chronicity between 1-3 weeks.

\section{RESULTS}

The Daruharidra ChandanaMalahara Lepa provided a Highly Significant Effect on Pain, Burning sensation, Bleeding, Sphincter spasm and Number of ulcers. Triphala Choorna H.S With warm water relieves constipation.

\begin{tabular}{|c|c|c|c|c|c|c|c|c|}
\hline \multirow[t]{2}{*}{ Symptoms } & \multicolumn{3}{|c|}{ Mean score } & \multirow[t]{2}{*}{$\%$} & \multirow{2}{*}{$\begin{array}{l}\text { S.D } \\
\left(+\_\right)\end{array}$} & \multirow{2}{*}{$\begin{array}{l}\text { S.E } \\
\left(+\_\right)\end{array}$} & \multirow[t]{2}{*}{$\mathrm{t}$} & \multirow[t]{2}{*}{$\mathrm{p}$} \\
\hline & BT & AT & BT-AT & & & & & \\
\hline Pain & 03 & 0.2 & 2.8 & $93.33 \%$ & 0.69 & 0.09 & 54.45 & $<0.001$ \\
\hline Bleeding & 02 & 0.80 & 1.2 & $56.25 \%$ & 0.745 & 0.009 & 10.62 & $<0.001$ \\
\hline Burning sensation & 01 & 00 & 1.00 & $100 \%$ & 00 & 00 & 00 & $<0.001$ \\
\hline Hard stools & 01 & 00 & 01 & $100 \%$ & 00 & 00 & 00 & $<0.001$ \\
\hline Tenderness & 03 & 0.45 & 2.55 & $44.44 \%$ & 0.630 & 0.009 & 10.95 & $<0.001$ \\
\hline Lenght of ulcer & 01 & 0.15 & 0.85 & $85 \%$ & 0.366 & 0.82 & 7.76 & $<0.001$ \\
\hline Sphincter spasm & 01 & 00 & 01 & $100 \%$ & 00 & 00 & 00 & $<0.001$ \\
\hline
\end{tabular}

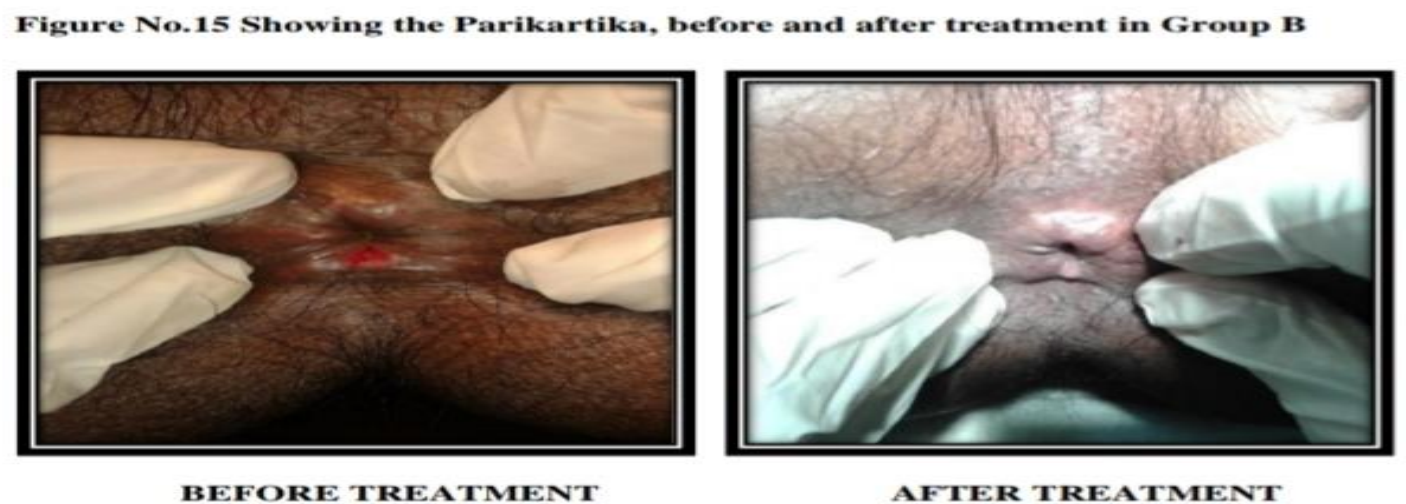




\section{DISCUSSION}

Shoola in Parikartika is mainly due to vata dosha aggravation and as per Modern Science; Pain is due to Inflammation and Sphincter Spasm. Hence Rujahara, (Pain relieve), Vatanulomana, Analgesic, Antiinflammatory Properties of Daruharidra Chandana helps in reducing the Pain by Decreasing the Anal Canal pressure and Hypertonicity of Sphincter Muscles when it is Applied in the form of Malahara. Daruharidra Chandana Malahara made an ointment tube. with an Applicator apply Daily for 7 days. By this Vata Dosha Shamana occurs and there by pain decreased. Daha in Parikartika is mainly due to increased Pitta Dosha, Hence Pittahara \& Dahashamaka. properties of Daruharidra Chandana helps in reducing the burning sensation. Raktasrava in Parikartika is mainly due to Increased Pitta Dosha and presence of Vrana in Gudapradesha and as per Modern Science, in Fissure-in-ano due to Straining for Constipated Hard Stools a Longitudinal Ulcer or tear in lower Anal canal forms, from their passing Streaks of Blood seen in Stools. Hence Pittahara and VranaRopana properties of Daruharidra Chandana help in controlling Bleeding per Anum. Vibandha (Constipation), in Parikartika is mainly due to Varchasavrita Apanavata, where Vata gets Aavruta with Pureesha/varcha, the Stool gets Constipated, and the patient passes Sushka shakrit (hard stools) with difficulty. And as per Modern Science Constipation is the Prime Causative Factor in the occurrence of Fissurein-ano. Hence Daruharidra Chandana is administered. in the form of Malahara Lepa Daily for 7 days by this Vatanulomana and Softening of Stool occurs, and Constipation got relieved. Patients were asked to Follow a pathya i'e. Daily intake of Fibre rich food and Plenty of fluids to improve Digestion and Regularize Bowels. Triphala Choorna is advised to take One Karsha Daily at Bedtime after food, which helps in the easy Evacuation of Bowels due to its Mrudu Virechaka property. The presence of Vrana in Gudapradesha is a Feature of Parikartika. As per Modern Science in Fissure-in-ano due to Straining for Constipated Hard Stools a Longitudinal Ulcer or tear in the lower anal canal forms by rupturing one of the anal valves. Hence Vranaropaka property of Daruharidra Chandana Malahara Lepa helps in the Healing of the Ulcer. Daruharidra Chandana is administered. in the form of Malahara lepa daily, by that Medicament cover the Ulcer Surface with Snigdha Dravya, by which the Wound contamination with faecal matter is avoided and this may enhance the Healing process. This Sphincter spasm can be attributed to vata dosha aggravation. As per Modern science, Constipation mainly leads to Ulcers following Pain which Finally ends up in Sphincter spasm as the lower anal canal is Supplied with the same somatic nerves, which supply the sphincter muscles. So, any Irritation to the Lower part of the Anal canal will cause these Sphincters to go into Spasm. Hence Daruharidra Chandana was administered warmly in the form of Malahara Lepa with an applicator for 7 days. By this daily Lubrication of the anorectal route, anal canal pressure is reduced. Hence, we can expect anal spasms to be relieved by this Treatment.

\section{CONCLUSION}

The Procedures in Both the Methods were similar, i.e., Malahara lepa which were simple, Economical, and free from side effects and did not require Hospitalization and could be carried out at the OPD level itself. Malahara lepa will helps in relieving the Sphincter spasm as there was the Retention of medicament; also, its contact with the lesion was there for a Longer Duration and together helped in Healing the Fissure quickly. It Lubricates the Anal canal and provides easy Evacuation of Faeces and thus promotes Healing of the Fissure Panchavalkala Malahara Lepa was also found effective in relieving Pain, burning sensation, Bleeding, and healing of Fissure-in-Ano. Management of Parikartika by Daruharidra Chandana Malahara Lepa was found to be Significant Statistically when compared with Management of Parikartika by Panchavalkala with a p-value of $>0.05$. However Individually, the method of Management of the Disease in both groups was Efficacious. Both methods of treatment have proved to be effective in the Management of Parikartika. But comparatively, Daruharidra Chandana Malhara Lepa had better results. 


\section{REFERENCES}

1. Agnivesha, Charaka, Drudhabala, Chakrapanidatta. Siddisthana chapter 6 verse 61-62. In: Acharya YT (edi). Charak Samhita with Ayurveda Deepika commentary. Reprint Edition, 2018: Varanasi: Chaukhamba Publication, pp- 1027.

2. Sushruta. Sushruta Samhita - with the Nibandhasangraha Commentry of Sri Dalhanacharyaand the NyayachandrikaPanjika of Sri Gayadasacharya on Chikitsasthana, edited by Yadavji Trikamji Acharya. Varanasi: Chaukhambha Orientalia, Varanasi, Reprint 2014. Chikitsa Sthana 34/16.

3. Kashyapa: Kashyapa Samhita preached by Maharshi maricha Kashyap; summarised and written by his disciple Acharya vruddajivika; redacted by latter's descendant vatsya; text with English Translation and commentary, edited by P.V. Tewari, ChaukambhaViswabharati; Reprint - 2014; Chikitsasthana; chapter 2.

4. Bailys and love the short practice of surgery $24^{\text {th }}$ ed.pp.1253-1254.

5. Vagbhata. Ashtanga Hridaya with the commentaries Sarvangasunara of Arunadatta and Ayurveda rasayana of Hemadri, collated by LateDr Anna Moreshwar Kunte \& krsna Ramachandra Shastri Navare edited by Bishagacharya Harisastri paradakara vaidya; Chaukamba orientalia; $10^{\text {th }}$ edi; Reprint- 2014; Uttara tantra 26/55.

6. Sushruta. Sushruta samhita - with the Nibandhasangraha Commentry of Sri Dalhanacharya And the Nyayachandrika Panjika of Sri Gayadasacharya on Chikitsasthana, edited by Yadavji Trikamji Acharya. Varanasi: Chaukhambha Orientalia, Varanasi, Reprint 2014. Chikitsa sthana 34/16.

7. Susruta- Sushruta Samhita -Text with English translation by P V Sharma. 1st ed. Varanasi: Chaukhambha Vishwabharati; 2005. Vol II. Chikitsa sthana $2^{\text {nd }}$ chap/ $67^{\text {th }}$ sloka.

\section{Source of Support: Nil \\ Conflict of Interest: None Declared}

How to cite this URL: Suresh Y. Bhajantri et al: Evaluation Of Efficacy Of Daruharidra Chandana Malahara Lepa And Panchavalkala Malahara Lepa In Parikartika With Special Reference To Acute Fissure In Ano. International Ayurvedic Medical Journal \{online\} 2021 \{cited August 2021\} Available from: http://www.iamj.in/posts/images/upload/1623 1628.pdf 